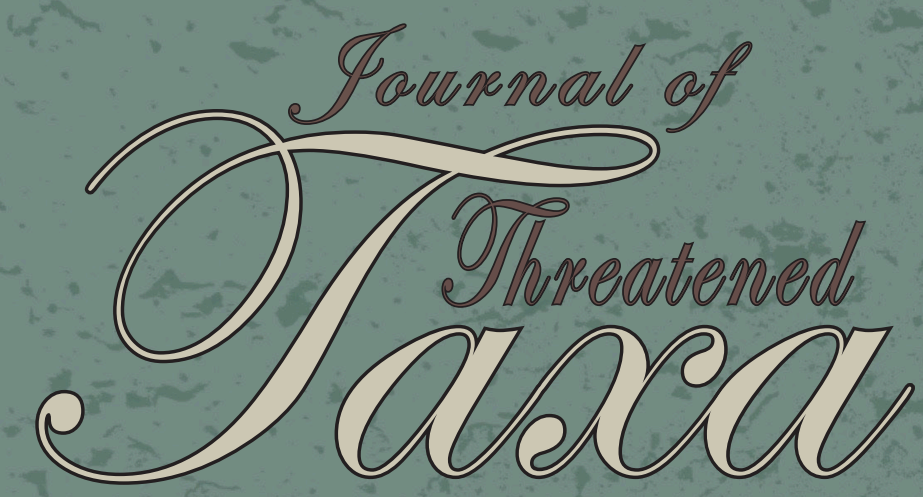

Building evidence for conservation globally
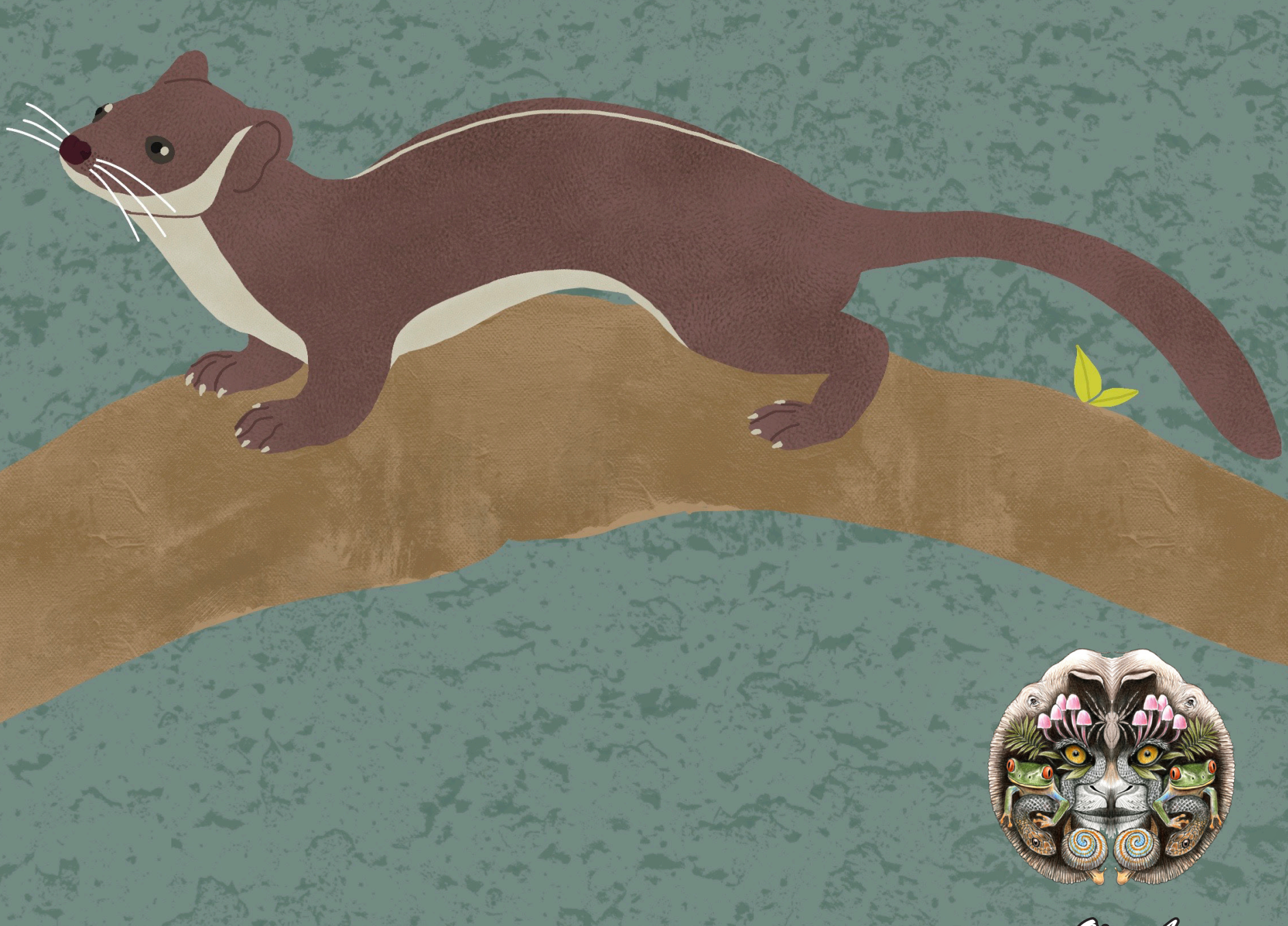

Qpecosecess

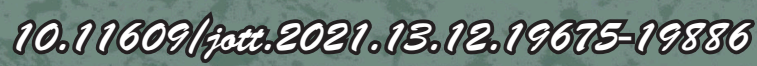
cocosurthreatecredtassararg

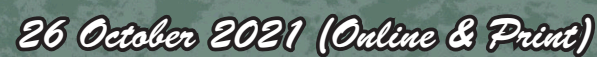

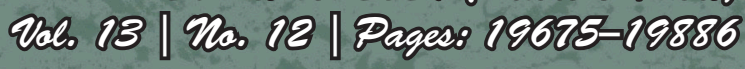




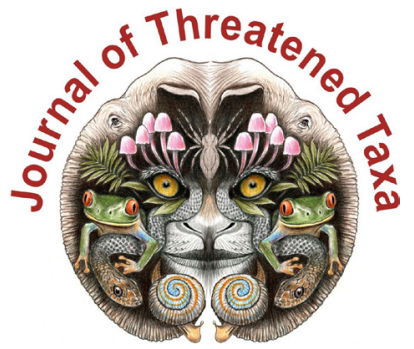

ISSN 0974-7907 (Online); ISSN $0974-7893$ (Print)

Publisher

Host

Wildlife Information Liaison Development Society

www.wild.zooreach.org

Zoo Outreach Organization www.zooreach.org

No. 12, Thiruvannamalai Nagar, Saravanampatti - Kalapatti Road, Saravanampatti, Coimbatore, Tamil Nadu 641035, India

Ph: +91 9385339863 | www.threatenedtaxa.org

Email: sanjay@threatenedtaxa.org

EDITORS

\section{Founder \& Chief Editor}

Dr. Sanjay Molur

Wildlife Information Liaison Development (WILD) Society \& Zoo Outreach Organization (ZOO)

12 Thiruvannamalai Nagar, Saravanampatti, Coimbatore, Tamil Nadu 641035, India

\section{Deputy Chief Edito}

Dr. Neelesh Dahanukar

Noida, Uttar Pradesh, India

\section{Managing Editor}

Mr. B. Ravichandran, WILD/ZOO, Coimbatore, India

\section{Associate Editors}

Dr. Mandar Paingankar, Government Science College Gadchiroli, Maharashtra 442605, India Dr. Ulrike Streicher, Wildlife Veterinarian, Eugene, Oregon, USA

Ms. Priyanka Iyer, ZOO/WILD, Coimbatore, Tamil Nadu 641035, India

Dr. B. A. Daniel, $200 /$ WIID, Coimbatore, Tamil Nadu 641035, India

\section{Editorial Board}

Dr. Russel Mittermeie

Executive Vice Chair, Conservation International, Arlington, Virginia 22202, USA

\section{Prof. Mewa Singh Ph.D., FASc, FNA, FNASc, FNAPsy}

Ramanna Fellow and Life-Long Distinguished Professor, Biopsychology Laboratory, and Institute of Excellence, University of Mysore, Mysuru, Karnataka 570006, India; Honorary Professor, Jawaharlal Nehru Centre for Advanced Scientific Research, Bangalore; and Adjunct Professor, National Institute of Advanced Studies, Bangalore

\section{Stephen D. Nash}

Scientific Illustrator, Conservation International, Dept. of Anatomical Sciences, Health Sciences Center, T-8, Room 045, Stony Brook University, Stony Brook, NY 11794-8081, USA

\section{Dr. Fred Pluthero}

Toronto, Canada

\section{Dr. Priya Davidar}

Sigur Nature Trust, Chadapatti, Mavinhalla PO, Nilgiris, Tamil Nadu 643223, India

\section{Dr. Martin Fisher}

Senior Associate Professor, Battcock Centre for Experimental Astrophysics, Cavendish

Laboratory, JJ Thomson Avenue, Cambridge CB3 OHE, UK

\section{Dr. John Fellowes}

Honorary Assistant Professor, The Kadoorie Institute, 8/F, T.T. Tsui Building, The University of Hong Kong, Pokfulam Road, Hong Kong

\section{Prof. Dr. Mirco Solé}

Universidade Estadual de Santa Cruz, Departamento de Ciências Biológicas, Vice-coordenado do Programa de Pós-Graduação em Zoologia, Rodovia Ilhéus/Itabuna, Km 16 (45662-000)

Salobrinho, Ilhéus - Bahia - Brasil

\section{Dr. Rajeev Raghavan}

Professor of Taxonomy, Kerala University of Fisheries \& Ocean Studies, Kochi, Kerala, India

\section{English Editors}

Mrs. Mira Bhojwani, Pune, India

Dr. Fred Pluthero, Toronto, Canad

Mr. P. Ilangovan, Chennai, India

Web Maintenance

Mrs. Latha G. Ravikumar, ZOO/WILD, Coimbatore, India

\section{Typesetting}

Mr. Arul Jagadish, ZOO, Coimbatore, India

Mrs. Radhika, ZOO, Coimbatore, India

Mrs. Geetha, ZOO, Coimbatore India

\section{Fundraising/Communications}

Mrs. Payal B. Molur, Coimbatore, India

Subject Editors 2018-2020

Fungi

Dr. B. Shivaraju, Bengaluru, Karnataka, India

Dr. R.K. Verma, Tropical Forest Research Institute, Jabalpur, India

Dr. Vatsavaya S. Raju, Kakatiay University, Warangal, Andhra Pradesh, India

Dr. M. Krishnappa, Jnana Sahyadri, Kuvempu University, Shimoga, Karnataka, India

Dr. K.R. Sridhar, Mangalore University, Mangalagangotri, Mangalore, Karnataka, India

Dr. Gunjan Biswas, Vidyasagar University, Midnapore, West Bengal, India

Plants

Dr. G.P. Sinha, Botanical Survey of India, Allahabad, India

Dr. N.P. Balakrishnan, Ret. Joint Director, BSI, Coimbatore, India

Dr. Shonil Bhagwat, Open University and University of Oxford, UK

Prof. D.J. Bhat, Retd. Professor, Goa University, Goa, India

Dr. Ferdinando Boero, Università del Salento, Lecce, Italy

Dr. Dale R. Calder, Royal Ontaro Museum, Toronto, Ontario, Canada

Dr. Cleofas Cervancia, Univ. of Philippines Los Baños College Laguna, Philippines

Dr. F.B. Vincent Florens, University of Mauritius, Mauritius

Dr. Merlin Franco, Curtin University, Malaysia

Dr. V. Irudayaraj, St. Xavier's College, Palayamkottai, Tamil Nadu, India

Dr. B.S. Kholia, Botanical Survey of India, Gangtok, Sikkim, India

Dr. Pankaj Kumar, Kadoorie Farm and Botanic Garden Corporation, Hong Kong S.A.R., China

Dr. V. Sampath Kumar, Botanical Survey of India, Howrah, West Bengal, India

Dr. A.J. Solomon Raju, Andhra University, Visakhapatnam, India

Dr. Vijayasankar Raman, University of Mississippi, USA

Dr. B. Ravi Prasad Rao, Sri Krishnadevaraya University, Anantpur, India

Dr. K. Ravikumar, FRLHT, Bengaluru, Karnataka, India

Dr. Aparna Watve, Pune, Maharashtra, India

Dr. Qiang Liu, Xishuangbanna Tropical Botanical Garden, Yunnan, China

Dr. Noor Azhar Mohamed Shazili, Universiti Malaysia Terengganu, Kuala Terengganu, Malaysia Dr. M.K. Vasudeva Rao, Shiv Ranjani Housing Society, Pune, Maharashtra, India

Prof. A.J. Solomon Raju, Andhra University, Visakhapatnam, India

Dr. Mandar Datar, Agharkar Research Institute, Pune, Maharashtra, India

Dr. M.K. Janarthanam, Goa University, Goa, India

Dr. K. Karthigeyan, Botanical Survey of India, India

Dr. Errol Vela, University of Montpellier, Montpellier, France

Dr. P. Lakshminarasimhan, Botanical Survey of India, Howrah, India

Dr. Larry R. Noblick, Montgomery Botanical Center, Miami, USA

Dr. K. Haridasan, Pallavur, Palakkad District, Kerala, India

Dr. Analinda Manila-Fajard, University of the Philippines Los Banos, Laguna, Philippines

Dr. P.A. Sinu, Central University of Kerala, Kasaragod, Kerala, India

Dr. Afroz Alam, Banasthali Vidyapith (accredited A grade by NAAC), Rajasthan, India

Dr. K.P. Rajesh, Zamorin's Guruvayurappan College, GA College PO, Kozhikode, Kerala, India

Dr. David E. Boufford, Harvard University Herbaria, Cambridge, MA 02138-2020, USA

Dr. Ritesh Kumar Choudhary, Agharkar Research Institute, Pune, Maharashtra, India

Dr. Navendu Page, Wildlife Institute of India, Chandrabani, Dehradun, Uttarakhand, India

Invertebrates

Dr. R.K. Avasthi, Rohtak University, Haryana, India

Dr. D.B. Bastawade, Maharashtra, India

Dr. Partha Pratim Bhattacharjee, Tripura University, Suryamaninagar, India

Dr. Kailash Chandra, Zoological Survey of India, Jabalpur, Madhya Pradesh, India

Dr. Ansie Dippenaar-Schoeman, University of Pretoria, Queenswood, South Africa

Dr. Rory Dow, National Museum of natural History Naturalis, The Netherlands

Dr. Brian Fisher, California Academy of Sciences, USA

Dr. Richard Gallon, llandudno, North Wales, LL30 1UP

Dr. Hemant V. Ghate, Modern College, Pune, India

Dr. M. Monwar Hossain, Jahangirnagar University, Dhaka, Bangladesh

Mr. Jatishwor Singh Irungbam, Biology Centre CAS, Branišovská, Czech Republic.

Dr. lan J. Kitching, Natural History Museum, Cromwell Road, UK

Dr. George Mathew, Kerala Forest Research Institute, Peechi, India

Dr. John Noyes, Natural History Museum, London, UK

For Focus, Scope, Aims, and Policies, visit https://threatenedtaxa.org/index.php/JoTT/aims_scope
For Article Submission Guidelines, visit https://threatenedtaxa.org/index.php/JoTT/about/submissions
For Policies against Scientific Misconduct, visit https://threatenedtaxa.org/index.php/JoTT/policies_various

continued on the back inside cover 


\title{
Population status of Heritiera fomes Buch.-Ham., a threatened species from Mahanadi Mangrove Wetland, India
}

\section{Sudam Charan Sahu ${ }^{1}$ (D), Manas Ranjan Mohanta ${ }^{2}$ (1) \& N.H. Ravindranath ${ }^{3}$}

\author{
1,2 Maharaja Sriram Chandra Bhanjadeo University (Erstwhile North Orissa University), Baripada, Odisha 757003, India. \\ ${ }^{3}$ Centre for Sustainable Technologies, Indian Institute of Science, Bengaluru, Karnataka 560012, India. \\ ${ }^{1}$ sudamsahu.bdk@gmail.com (corresponding author), ${ }^{2}$ manasranjan.mrm@gmail.com, ${ }^{3}$ ravi@ces.iisc.ernet.in
}

\begin{abstract}
Heritiera fomes Buch.-Ham. is assessed as an endangered mangrove species by IUCN, and information on population status is lacking. The present study assesses the status of H. fomes in Mahanadi Mangrove Wetland on the east coast of India. Three forest blocks were selected and sampled for this study. Among these, the mean girth at breast height (GBH) of $H$. fomes was the highest in Hetamundia $(H D)$ forest block. GBH of $H$. fomes was inversely proportional to the cumulative disturbance index $\left(R^{2}=0.7244, p\right.$ value $<0.005)$. The relative density was maximum for $\mathrm{H}$. fomes $(56 \%)$ at Bhitarkharnasi (BK), and for Excoecaria agallocha at Hetamundia (HD; $35 \%) \&$ Kansaridia (KD; 54\%), respectively. Excoecaria agallocha is a dominant species possibly impacting natural populations of $H$. fomes. Climate change and rising sea levels may also negatively affect the existence of this species. Therefore, appropriate strategies should be taken for conservation of this globally threatened mangrove species prior to its extinction.
\end{abstract}

Keywords: Conservation, disturbance index, diversity indices, East Coast of India, relative density, threatened mangroves.

Citation: Sahu, S.C., M.R. Mohanta \& N.H. Ravindranath (2021). Population status of Heritiera fomes Buch.-Ham., a threatened species from Mahanadi Mangrove Wetland, India. Journal of Threatened Taxa 13(12): 19791-19798. https://doi.org/10.11609/jott.7018.13.12.19791-19798

Copyright: (C) Sahu et al 2021. Creative Commons Attribution 4.0 International License. JoTT allows unrestricted use, reproduction, and distribution of this article in any medium by providing adequate credit to the author(s) and the source of publication.

Funding: SERB, Department of Science and Technology, Government of India [Project file No. SB/FT/LS- 122/2012].

Competing interests: The authors declare no competing interests.

Author details: SUDAM CHARAN SAHU, MSc, PhD, F.I.A.T. is working as an assistant professor in the Department of Botany, Maharaja Sriram Chandra Bhanjadeo University, Baripada (Odisha), India. His specialization and research fields include plant taxonomy, ethnobotany, forest ecology, climate change and biodiversity conservation. He is recognized as Fellow of Indian Association for Angiosperm Taxonomy. MANAS RANJAN MoHANTA (MSc, MPhil in Botany) is doing his PhD in botany at Maharaja Sriram Chandra Bhanjadeo University, Odisha, since 2017. He is an active researcher in the field of biodiversity, ecology and climate change. PROF. N.H. RAVINDRANATH is working as professor (Retd.) in the Centre for Sustainable Technologies, Indian Institute of Science Bangalore, India. He focused his research, advocacy and publications on various dimensions of climate change -mitigation assessment, impact of climate change and vulnerability assessment in forest and agro-ecosystems, adaptation and climate resilience, forest ecology, CDM and REDD+ Projects.

Author contribution: Study design: NHR, SCS. Fieldwork: SCS, MRM. Data analysis: SCS Writing: SCS, MRM Feedback: NHR, SCS.

Acknowledgements: We are thankful to the SERB, Department of Science and Technology, Government of India for necessary funding and the forest department, Government of Odisha, for allowing to work inside the forest.
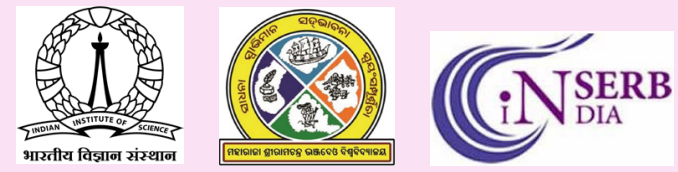


\section{INTRODUCTION}

Mangrove ecosystems are important with respect to their contribution towards biodiversity, carbon storage, ecosystem balance, prevention of soil erosion, economic development, health care and protection against natural calamities (Ellison 2008). Mangrove flora are major reservoirs of biological carbon that contribute significantly towards mitigation of climate change (Mohanta et al. 2020). The social economy in coastal areas is highly dependent on vegetation directly or indirectly through fishing activity, tourism, and medication (Alongi 2008).

Lack of conservation and protection of mangrove habitats in recent decades has resulted in sparse distribution of species and regional extinctions; $35 \%$ of mangrove area was lost between 1980-1990 alone worldwide (Valiela et al. 2001). However, an increase in land cover by mangroves has been observed over the last few years in some Indian states, including Maharashtra, Gujrat, Odisha, and Andhra Pradesh (ISFR 2017; Khare \& Shah 2019). Odisha has $243 \mathrm{~km}^{2}$ under mangrove vegetation in the coastal districts of Balasore, Bhadrak, Jagatsinghpr, Kendrapara, and Puri (ISFR 2017).

Information on threatened species is needed for formulation of conservation policies helpful in defining marine protected areas and resource utilization for coastal development (Polidoro et al. 2010). Studies of distribution, ecology, adaptation, and threat assessment are all prerequisites for effective management of resources in general, and threatened species in particular (Lewis et al. 2016; George et al. 2019). Recent global assessment reveals that $16 \%$ of total species of mangrove (70) are under threat of extinction.

In India, two species, Heritiera fomes Buch.-Ham. (Endangered) and Sonneratia griffithii Kurz (Critically Endangered) are under the IUCN category of threatened species (Polidoro et al. 2010). H. fomes (Sterculiaceae) is native to India, Bangladesh, Malaysia, Myanmar, and Thailand. In India, it is found only in the Sundarbans in West Bengal, and Bhitarkanika (abundant) and Mahanadi Mangrove Wetland (MMW; rare) in Odisha. $H$. fomes is locally called 'Bada Sundari' in Odisha. It mostly grows towards landward in low saline (5-15 PSU) habitats with fresh water association in upstream estuarine zones and in high intertidal regions. Climate change, sea level rise and salinification of coastal habitats have had adverse effects on sustainability of this species in different habitats. Hence, it can be taken as an indicator of global climate change and sea level rise.

H. fomes is an important traditional medicinal plant, with reported activity to treat infections and diseases including goiter, skin diseases, gastrointestinal disorders, diabetes, and cancer (Mahmud et al. 2014; Islam et al. 2019). Timbers of the plant have high utility due to their hard and elastic nature. The timbers are used as constructive material for bridges, houses, boats, and hard boards (Ghosh et al. 2004). Locally, the timber is used as fire wood as well. However, the species is disappearing due to absence of fresh water and low seed viability (Kathiresan 2010). There is chance of local extinction of $H$. fomes in India as populations are declining rapidly due to anthropogenic and natural pressures (Kathiresan 2010). In Bangladesh, the species is facing the problem of dieback causing a severe loss of mangroves (Hussain \& Acharya 1994). Due to its threat of extinction and lack of data regarding its population structure, it is essential to assess the population status of $\mathrm{H}$. fomes for further planning to conserve and manage this species.

\section{MATERIALS AND METHODS}

\section{Study area}

The Mahanadi mangrove wetland is located on the eastern coast of India in Kendrapara district of Odisha, which lies between 20.30-20.53 N and 86.66-86.80 E. The area is covered with dense mangrove forest which extends from Hukitola Bay (North) to Paradip Port (South). The climate of the area is generally tropical monsoon in nature, with about $2,000 \mathrm{~mm}$ of rainfall annually. The area faces severe cyclonic storms each year peaking during May-July and October-November. The tidal amplitude ranges as high as $6 \mathrm{~m}$ during monsoon and as low as $1.2 \mathrm{~m}$. in dry seasons. The combination of fresh water streams and tidal water in the inter-tidal regions of the Mahanadi river mouth provide luxuriant habitats for mangrove flora. However, there is variation in the salinity level at different seasons, and areas based on the precipitation and distance from sea to river and creeks, respectively. The salinity level of water becomes higher as 11.5 to 19.9 pptv near the sea and becomes lower at interior mangrove regions (landward) as 0.3 to 0.7 pptv (Ravishankar et al. 2004). The wet land is divided into eight forest blocks, i.e., Kansaridia (KD), Bhahar Kharnasi (BK), Bhitar Kharnasi (BK), Hukitola, Jambu, Kantilo, Kendrapatia, and Hatamundia. In these forest blocks two important species Heriteira fomes and Sonneratia griffithii are found which are considered as globally threatened plant species. 


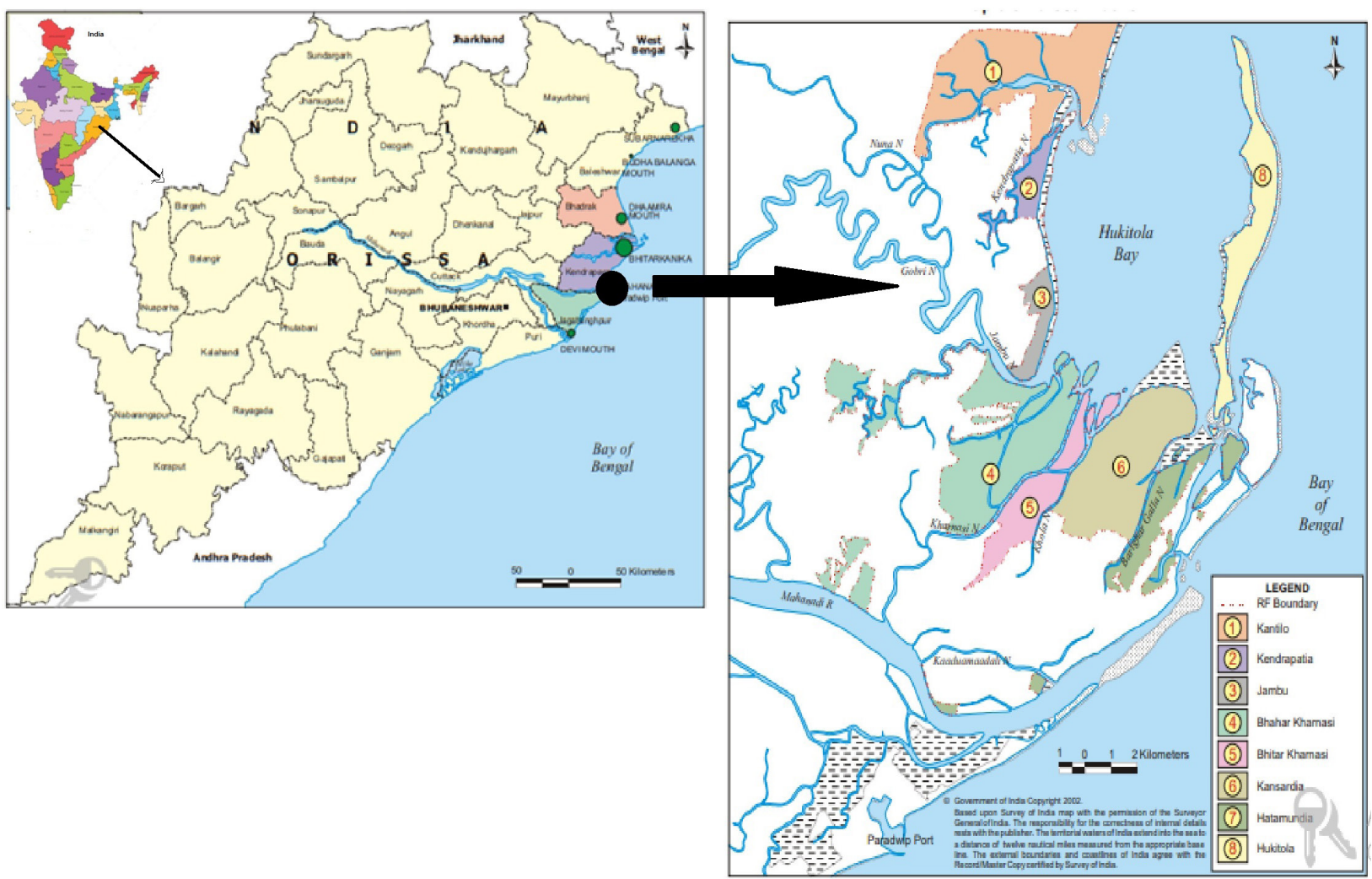

Figure 1. Study area showing forest blocks of Mahanadi Mangrove Wetland (MMW) (Adapted from Atlas of mangrove wetlands of India, part3, Odisha).

\section{Data collection}

Field surveys were carried out to study the population status of $H$. fomes in MMW from 2013 to 2016. After searching all the forest blocks of MMW, this species was found only in three reserve forests: Bhitarkharnasi (BK), Hetamundia (HD), and Kansaridia (KD). We laid nine quadrats $(20 \times 20 \mathrm{~m})$ in total, three in each forest block. Woody trees with $\mathrm{GBH} \geq 10 \mathrm{~cm}$ were considered for the study. The size class wise distribution of plants was estimated considering three levels, i.e., $<10 \mathrm{~cm}$ (lower GBH class), 10-20 cm (mid GBH class), and $\geq 20$ $\mathrm{cm}$ (higher $\mathrm{GBH}$ class). Distributions of plants in these classes were compared to understand the future trend of distribution of the species. To study the regeneration status of $H$. fomes, stems $<10 \mathrm{~cm}$ girth were counted and recorded under each plot. For studying the stem size class distribution, plants with $<10 \mathrm{~cm}$ GBH were treated as seedlings and those of $\geq 10 \mathrm{~cm} \mathrm{GBH}$ as trees (Pascal 1988). The global positioning system (GPSGarmin Oregon-600) was used to record spatial location (latitude, longitude, and altitude) of each quadrat.

The data were analyzed through different diversity indices (Shannon-Weiner index and Simpson's index) and other diversity parameters (Menhinick's species richness and evenness) following Magurran (2004).

Relative density was also calculated following the formula,

Relative Density $=100 *$ (Density of one species/ Density of all species)

where, density was calculated as number of individuals of the species/ha.

Each forest block was observed to determine the type and level of disturbance following Tadwalkar et al. (2012). Observations were based on disease infection, cut stumps, and salinity of tidal water. These three features were measured through four levels, i.e., $0=$ no impact, 1= low impact, 2= moderate impact, and 3= high impact (Patwardhan et al. 2016). Cut stumps were taken as a sign of active anthropogenic disturbance whereas salinity of tidal water and disease infections were as natural disturbances. The salinity of the water was determined by following standard methodology given by APHA (2005). A cumulative disturbance index (CDI) was estimated for different forest blocks by adding these three scores. The estimated CDI were compared against other diversity parameters and mean $\mathrm{GBH}$ values of $H$. fomes in different forest blocks to evaluate the correlation between them. 


\section{RESULTS AND DISCUSSION}

Among eight studied forest blocks, $H$. fomes was found only in three: Bhitarkharnasi (BK), Hetamundia (HD), and Kansaridia (KD) reserve forests. These forest blocks comparatively represented with low salinity conditions due to absence of continuous tidal water. The cumulative species richness of all the studied plots was 10, including a single herb species named Acanthus ilicifolius L. The other woody species were $H$. fomes, Excoecaria agallocha L., Cynometra iripa Kostel., Xylocarpus granatum J.Koenig., Avicennia officinalis L., Phoenix palludosa Roxb., Ceriops tagal (Perr.) C.B.Rob., Pongamia pinnata (L.) Pierre, and Rhizophora apiculata Blume. H. fomes was found to occur at an altitude of 6-25 $\mathrm{m}$. The detailed ecological information of sampling sites is given in Table 1 . The Shannon diversity index varied among the three forest blocks as HD having the highest diversity index $(1.32 \pm 0.18)$ followed by KD $(1.26 \pm 0.01)$ and BK $(1.16 \pm 0.20)$ (Table 2). The overall Shannon diversity index was $1.25 \pm 0.15$. Simpson's Index was highest at $\mathrm{HD}(0.70 \pm 0.04)$ followed by KD $(0.64 \pm 0.01)$ and $\mathrm{BK}(0.60 \pm 0.09)$. Here, the HD seems to have better diversity than BK but closer to the KD. The visible variation in the diversity indices values is may be due to the differences in potential threat effects or soil nutrient status or both. However, the lower diversity indices of mangrove forest compared to other tropical forests ecosystem is quite common due to lower species richness (Gevana \& Pampolina 2009; Stanley \& Lewis 2009; Joshi \& Ghose 2014).

The total number of individuals of $H$. fomes recorded in nine plots ( $0.36 \mathrm{ha}$ ) of three forest blocks was 482 , including 398 trees and 84 regenerating individuals (Seedlings). BK possessed 231 individuals followed by
HD (133) and KD (118). The values of tree number in the region is quite satisfactory but number of seedlings was very low, indicated towards reduction of population size in future because the number of juveniles must exceed the number of trees to ensure population expansion (Upadhyay \& Mishra 2014). Similarly, for a stable population size these numbers should be equal or nearly equal to satisfy one to one replacement condition (Upadhyay \& Mishra 2014). But the cumulative result of these nine studied plots put the ratio near $5: 1$ (Tree : Seedlings), which indicates poor regeneration status of the species in the area and urgent need for conservation.

The distribution of $\mathrm{GBH}$ class revealed that in $\mathrm{BK}, 25$ individuals had stems less than $10 \mathrm{~cm} \mathrm{GBH}$ (seedlings), 78 had stems between $10-20 \mathrm{~cm}$, and 128 had stems greater than $20 \mathrm{~cm}$ (mature trees), indicating a healthy population structure with good representation of individuals of all size classes. In HD, stems less than 10 $\mathrm{cm} \mathrm{GBH}$ (seedlings) was 39 individuals followed by stems between $10-20 \mathrm{~cm}$ at 78 individuals and stems greater than $20 \mathrm{~cm}$ (mature trees) at 16 individuals. In KD, stems less than $10 \mathrm{~cm} \mathrm{GBH}$ (seedlings) was 20 individuals followed by stems between $10-20 \mathrm{~cm}$ at 64 individuals and stems greater than $20 \mathrm{~cm}$ (mature trees) at 34 individuals (Figure 2). Among these three forest blocks, there was a visible difference among of matured tree numbers. BK was bearing the highest number whereas it was lowest in $\mathrm{HD}$, indicating the difference in the level of potential threat among two blocks. The reason evaluated for less number of mature trees in HD was the more anthropogenic activities in the region (Highest CDI, Table 1). KD showed less number of seedlings than other forest blocks indicating poor regeneration status of $H$. fomes in this block. It may be due to more salinity $(6.8 \pm 1.2 \mathrm{pptv})$ and disease infection. The lowest salinity level $(4.7 \pm 1.5$

Table 1. Ecological information of study sites.

\begin{tabular}{|c|c|c|c|c|c|c|}
\hline $\begin{array}{c}\text { Forest block/ } \\
\text { Plot no. }\end{array}$ & $\begin{array}{c}\text { Latitude (degree, } \\
\text { minute) }\end{array}$ & $\begin{array}{c}\text { Longitude (degree } \\
\text { minute) }\end{array}$ & $\begin{array}{c}\text { Altitude } \\
\text { (meter) }\end{array}$ & $\begin{array}{c}\text { Density } \\
\text { (ha-1) }\end{array}$ & Mean GBH & CDI \\
\hline BK-1 & 20.393 & 86.719 & 21 & 2475 & 19.49 & 4 \\
\hline BK-2 & 20.364 & 86.719 & 25 & 1200 & 31.02 & 3 \\
\hline BK-3 & 20.371 & 86.726 & 23 & 2100 & 22.96 & 4 \\
\hline HD-1 & 20.352 & 86.767 & 13 & 1000 & 14.55 & 6 \\
\hline HD-2 & 20.355 & 86.768 & 9 & 1275 & 10.45 & 7 \\
\hline HD-3 & 20.35 & 86.765 & 6 & 1050 & 16.26 & 5 \\
\hline KD-1 & 20.368 & 86.763 & 17 & 1040 & 18.90 & 5 \\
\hline KD-2 & 20.369 & 86.719 & 16 & 925 & 15.40 & 6 \\
\hline KD-3 & 20.37 & 86.719 & 15 & 975 & 15.79 & 4 \\
\hline
\end{tabular}

BK-BhitarKharnasi | HD-Hetamundia | KD-Kansaridia (1, 2, 3 represents sampling plots). 
Table 2. Diversity indices in three forest blocks.

\begin{tabular}{|l|c|c|c|c|}
\hline Diversity index & Bhitarkharnasi (BK) & Hetamundia (HD) & Kansaridia (KD) & Overall \\
\hline Shannon-Weiner & $1.16 \pm 0.20$ & $1.32 \pm 0.18$ & $1.26 \pm 0.01$ & $1.25 \pm 0.15$ \\
\hline Simpson & $0.60 \pm 0.09$ & $0.70 \pm 0.04$ & $0.64 \pm 0.01$ & $0.65 \pm 0.06$ \\
\hline Evenness & $0.61 \pm 0.08$ & $0.72 \pm 0.09$ & $0.58 \pm 0.01$ & $0.64 \pm 0.09$ \\
\hline Menhinick & $0.45 \pm 0.03$ & $0.43 \pm 0.10$ & $0.51 \pm 0.01$ & $0.46 \pm 0.06$ \\
\hline
\end{tabular}

Note: mean \pm standard deviation are presented.

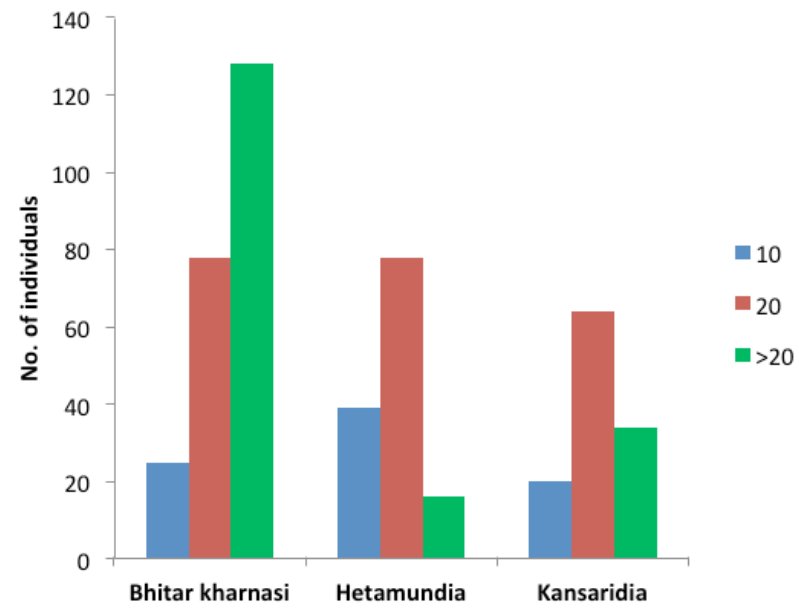

Figure 2. Distribution of no. of individual trees in different GBH classes (in $\mathrm{cm}$ ).

pptv) and moderate anthropogenic disturbance in BK supposed to support highest tree density and seedling density among blocks. Different parameters like viable seed number, germination, establishment, and growth are the indicators of regeneration of plant community and also structurally reforms the community based on the age group distribution to the habitat (Cunningham 2001). The relative density was highest for $H$. fomes (56\%) at Bhitarkharnasi and Excoecaria agallocha at HD (35\%) and KD (54\%), respectively (Figure 3). This indicates that Excoecaria agallocha is invading and dominating in a very fast rate due to its more ecological adaptations to the existing environmental conditions.

The mean $\mathrm{CDI}$ for the three forest blocks were: 3.36 $(\mathrm{BK}), 6(\mathrm{HD})$, and $5(\mathrm{KD})$. In the analysis, the $\mathrm{CDI}$ was found to be negatively correlated with mean $\mathrm{GBH}$ of each plot $\left(R^{2}=0.7244, p\right.$ value $\left.<0.005\right)$ (Figure 4). However, there was a clear indication cumulative disturbances in the distribution of higher GBH class individuals in HD. Similarly, the lowest mean CDI value in BK supported the maximum distribution of trees with higher GBH class. The CDI value did not show any significant correlation with other variables like density and altitude. However, it was found that CDI value was highest in the forest
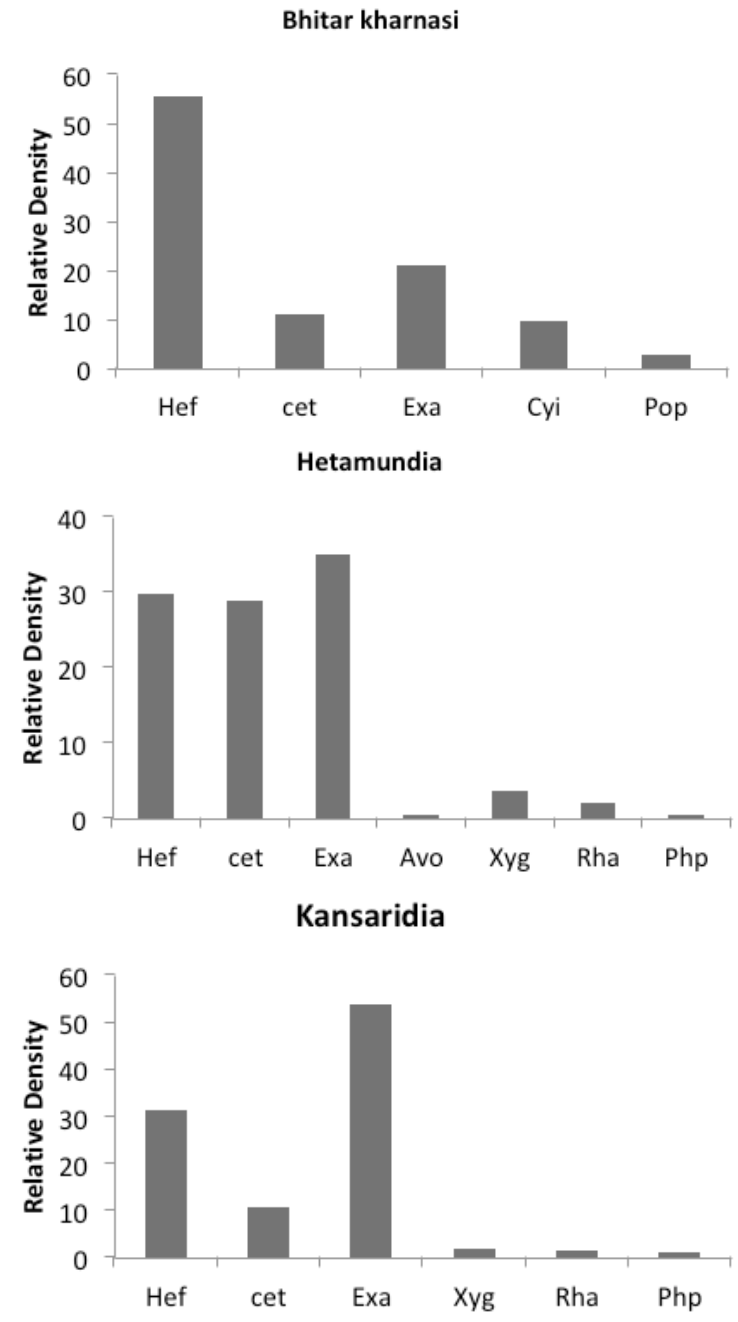

Figure 3. Relative density of $H$. fomes and its associated species. Hef- $\boldsymbol{H}$. fomes | Exa-Excoecaria agallocha | Cyi-Cynometra iripa | Xyg-Xylocarpus granatum | Avo-Avicennia officinalis | PhpPhoenix palludosa | Cet-Ceriops tagal | Pop-Pongamia pinnata | Rha-Rhizophora apiculata.

block at lower altitude and similarly it was less in higher altitude. This was clearly showing the tidal effect on habitat modification and distribution of flora. The density among study plots showed high variability, ranging from 925 to 2,475 individuals/hectare. Variation was also observed among plots within forest blocks, 

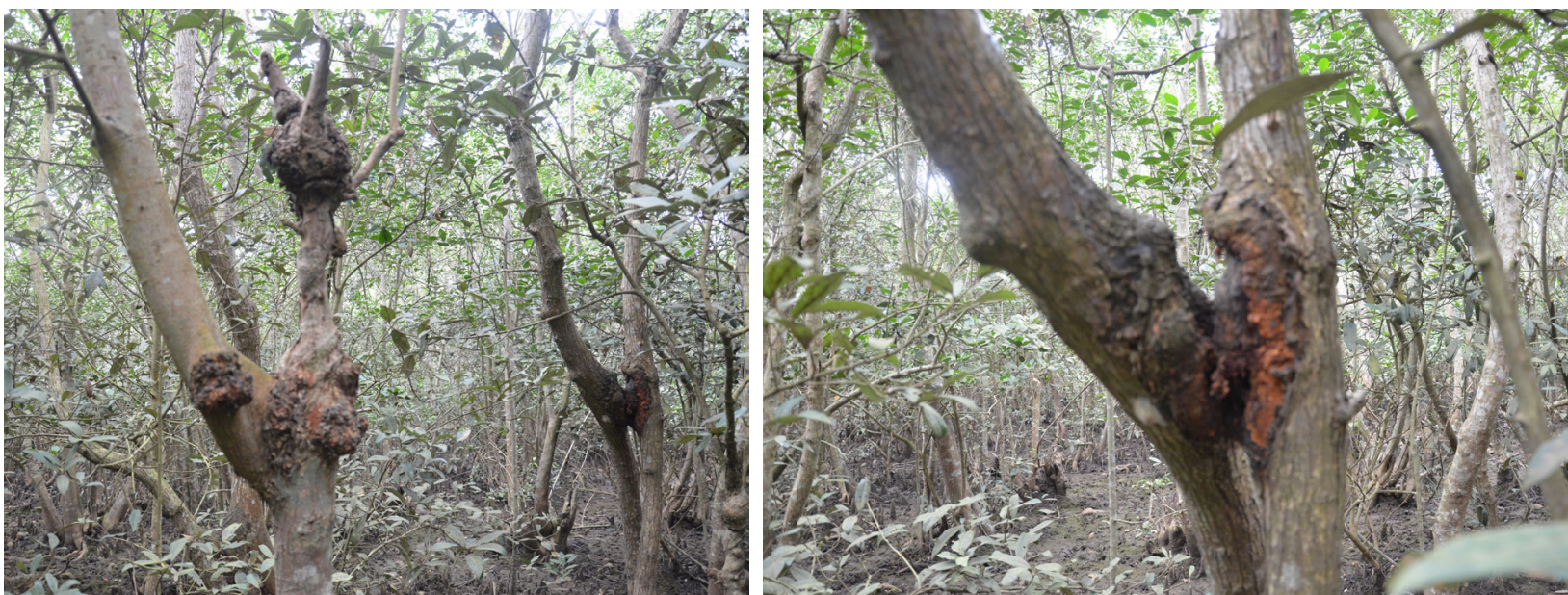

Image 1. H. fomes infected with gall cankers. (c) Sudam Charan Sahu.

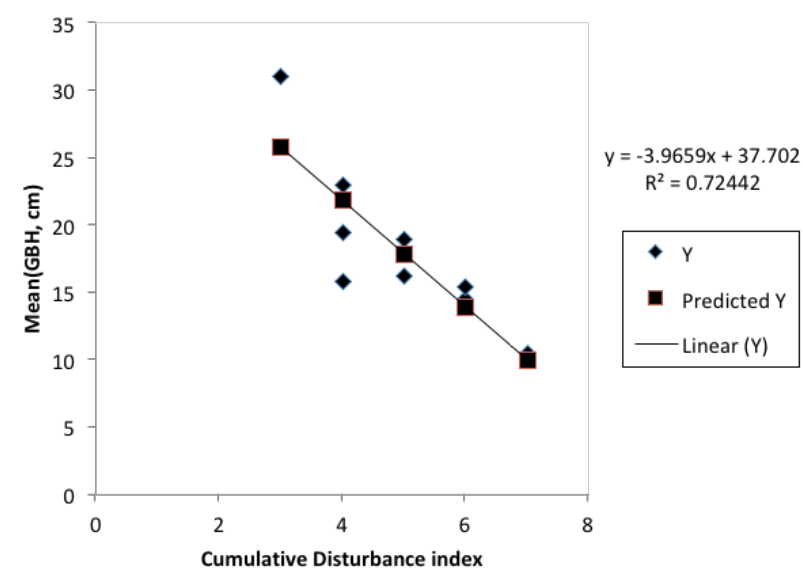

Figure 4. Cumulative disturbance index versus mean GBH.

being highest in $\mathrm{BK}$ and lowest in $\mathrm{KD}$. These variations are common due to uneven distribution of plants due to tidal effects and variations in soil nutrient status (Xin et al. 2013). The role of human disturbances cannot also not be ignored.

\section{Threats}

$H$. fomes grows well in low salinity condition about 2-5 PSU (Mitra et al. 2004; Ravishankar et al. 2004). Growth of mangroves is impacted by salinity level (Mitra et al. 2004). The higher salinity level in water affects the concentration of chlorophyll pigments $a$ and $b$ in leaves that decreases chances of sustainability of low salt tolerant plants in those regions (Clough 1985). Hence, salinity level can be a cause for stunted and rare distribution of flora or even to their regional extinction. In our study, lowest mean GBH was found in HD forest block indicating highest Cumulative Disturbance Index
(CDI) due to high salinity (5.4 \pm 1.3 pptv) and disease infection. In Bangladesh Sundarban, about $20 \%$ of the entire forests have been affected due to top dying disease in $H$. fomes (Kathiresan 2010). Natural conditions like excessive flooding, increased soil salinity, sedimentation, imbalance in soil nutrients, and cyclone induced threats are the known factors for the disease. In the present study we observed some $H$. fomes trees were infected with gall cankers (Image 1 ).

Biological invasion is a major threat to biodiversity (Biswas 2003; IUCN 2003). In the present study no known invasive species was reported, but the domination of some true mangrove species and their associates was observed which might be giving inter-specific competition to $H$. fomes in different aspects. These species of MMW might have impacts on the natural population of $H$. fomes in competing for light and nutrients to suppress natural regeneration and cause physical damage. We recorded seven such species belonging to seven families and seven genera. Out of seven species, Excoecaria agallocha L., Acanthus ilicifolius L., and Ceriops decandra (Griff.) W.Theob. are pre-dominating the study area. The distribution of $E$. agallocha and $C$. decandra in the region may also have negative impact over the $H$. fomes. It is because a previous study at Sundarban mangrove reported a negative association between $H$. fomes with E. agallocha and C. decandra (Ellison et al. 2000). Further, we assumed that the future environmental conditions may support extensive growth of Excoecaria agallocha in the region because the species is highly salt tolerant, faster growing, and have high ability to colonize in degraded habitats (Harun-or-Rashid et al. 2009). The other important species were Derris trifoliate Lour., Clerodendru minerme (L.) Gaertn., Eichhornia crassipes 
(Mart.) Solms, and Saccharum spontaneum L.. Although, the relationship $H$. fomes with these species is not clear but there must be a negative interaction in them that supposed to affect the regeneration of the species due to inter specific competitions. Hence, the nature of relationship between $H$. fomes and other invasive species is the part of future research.

The unscientific utilization and management of resources is a major threat to biodiversity. Globally, there is not been a single policy that ensures sustainable use and conservation of mangrove resources (Romanach et al. 2018). Repeated logging and unscientific exploitation of plant species force distributions to be sparse. However, the present condition in the study areas are much organized and restricted for logging and other activities due to active involvement of forest department. But extensive logging of large trees for construction and firewood in these areas was quite frequent in the past. The interaction with local people revealed that the information about the threat status of the species was completely unknown by the local communities. There was complete absence of awareness programs regarding environmental education and threatened species in the area among tribes. This was the one among the valid reasons for disperse distribution of the species.

The study site is located in the eastern coast of India where tropical cyclonic storms are very common, specifically the coast of Odisha state. Disastrous tsunamis with high tidal force and above $150 \mathrm{~km} / \mathrm{hr}$ wind speed severely affect coastal mangrove vegetation almost each year. Recent examples of such natural calamities are cyclone Phailin (2013), cyclone Hudhud (2014), and cyclone Fani (2019). The disastrous effect of the super cyclone in 1999 to the coastal areas of Odisha is well known. Apart from immediate damage, post-cyclonic changes in habitat create issues such as increased infections and temperature reduction (Shengyan et al. 2019). Thus it is a major challenge for forest managers to protect mangrove diversity and effectively implement conservation strategies. In these conditions, the regeneration and sustainability of $H$. fomes is highly affected due increase in habitat salinity levels and disease after cyclones.

\section{Conservation measures}

Effective conservation measures are essential for the sustainability of $H$. fomes in the region. This can be achieved by supply of fresh water to high salinity areas, for better growth and regeneration. Preparation of specialized habitats and plantation areas with optimal salinity condition for $H$. fomes may aid conservation in the area. Further, plantation areas could be established at a safe distance from the sea so that required amounts of fresh and saline water can be channeled, and arrival of high tidal water during cyclones and other natural calamities prevented. The present policies of plantation of mangrove flora are quite successful in the area, but the active and effective participation of local people is lacking. Here, it can be suggested that the population strength of $H$. fomes in the area can be achieved through active participation of local people and taking the species at high priority.

$H$. fomes has been reported to be infected by different pests and diseases that directly affect regeneration. Hence, effective research to the problem is required to overcome this issue in an eco-friendly way. Use of artificial pesticides may be an option, but use of bio pesticides will be better for healthy ecosystem development. Germination of this species is low, and seedlings are few. Further study of germination and seed viability of this species in different environmental conditions is required.

Inter-specific competition is common in natural ecosystems, and it is a major determinant of population structures. Further study is needed to observe the impact of Excoecaria agallocha and other species on the life cycle of $\mathrm{H}$. fomes. The awareness programs regarding importance of biodiversity and sustainable utilization of the resources to be conducted in regular intervals in the coastal areas. Government and local community should involve in plantation of $H$. fomes in suitable areas where the salinity level is low and sufficient supply of fresh water is available. Tree cutting should be completely avoided providing alternative livelihood for the local communities. The Coconut plantation, oil extraction, tourism promotion, and small scale industry development can be seen as alternatives for livelihood development for the associate communities. Further, climate change and sea level rise may negatively affect existence of this species (increase in salinity level) and appropriate adaption strategies may be taken for conservation of the globally threatened mangrove species $H$. fomes prior to its extinction in the region.

In summary, well-organized and coordinated efforts of researchers, forest managers, and administrators are needed to achieve the goal of $\mathrm{H}$. fomes conservation. Fruitful investment of funds, effective implication of policies, continuous supervision, and evaluation are key to effective conservation strategies. 


\section{REFERENCES}

Alongi, D.M. (2008). Mangrove forests: resilience, protection from tsunamis, and responses to global climate change. Estuarine Coastal and Shelf Science 76(1): 1-13.

APHA (2005). Standard methods for the examination of water and waste water. $21^{\text {st }}$ edition, American Public Health.

Biswas, S.R. (2003). Invasive plants of Sundarbans. In: Interim report under SBCP project, IUCN Bangladesh, $34 \mathrm{pp}$.

Clough, B.F. (1985). Effect of nutrient supply on photosynthesis in mangroves, pp. 80-88. In: Bhosale, L.J. (ed.). The Mangroves. Proceeding of National Symposium on Biological Utilization and Conservation of Mangroves. Shivaji University, Kohlapur, India.

Cunningham, A.B. (2001). People, wild plant use and conservation. People and Plants conservation Manual. Appl. Ethnobotanique, Earthscan, $300 \mathrm{pp}$

Mukherjee, B. \& A. Karim (2000). Testing patterns of zonation in mangroves: Scale dependence and environmental correlates in the Sundarbans of Bangladesh. Journal of Ecology 88(5): 813-824.

Ellison, A.M. (2008). Managing mangroves with benthic biodiversity in mind: moving beyond roving banditry. Journal Sea Research 59(12): 2-15.

George, G., P. Krishnan, K.G. Mini, S.S. Salim, P. Ragavan, S.Y. Tenjing, R. Muruganandam, S.K. Dubey, A. Gopalkrishnan, R. Purvaja \& R. Ramesh (2019). Structure and regeneration status of mangrove patches along the estuarine and coastal stretches of Kerala, India. Journal of Forestry Research 30: 507-518.

Gevana, D.T. \& N.M. Pampolina (2009). Plant diversity and carbon storage of a Rhizopora stand in Verde Passage, San Juan, Batangas, Philippines. Journal of Environmental Science and Management 12(2): 1-10.

Ghosh, S.C., A.K.M.A. Bosunia, M.A. Islam \& A.K. Lahiry (2004) Physical properties variation of sound and top dying affected Sundri wood (Heritiera fomes) in mangrove forest of Bangladesh. International Research Group on Wood Preservation: $35^{\text {th }}$ Annual Meeting.

Harun-or-Rashid, S., S.R. Biswas, R. Böcker \& M. Kruse (2009). Mangrove community recovery potential after catastrophic disturbances in Bangladesh. Forest Ecology and Management 257(3): 923-930.

Hussain, K. \& G. Acharya (2010). Mangroves of the Sundarbans. Volume 2: Bangladesh. IUCN Wetlands Programme, Bangkok, Thailand.

ISFR (2017). Indian State of Forest Report. Forest Survey of India, Dehradun.

Islam, M.E., K.M.D. Islam, M.M. Billah, R. Biswas, M.H. Sohrab \& S.M.M. Rahman (2019). Antioxidant and anti-inflammatory activity of Heritiera fomes (Buch.-Ham), a mangrove plant of the Sundarbans. Advanced Traditional Medicine 20: 189-197. https:// doi.org/10.1007/s13596-019-00401-0

IUCN (2003). Status of the ecological integrity of the Sundarbans. IUCN Bangladesh Country Office, $80 \mathrm{pp}$.

Joshi, H.G. \& M. Ghose (2014). Community structure, species diversity and above ground biomass of the Sundarbans mangrove swamp. Tropical Ecology 55(3): 283-303.

Kathiresan, K. (2010). Globally threatened mangrove species in India. Current Science 98(12): 15-51.

Khare S.S. \& D.G. Shah (2019). Mangrove vegetation change in Vagra Taluka, Bharuch district, Gujarat, India from 1978-2012. Indian Journal of Geo Marine Sciences 48(4): 504-510.
Lewis, R.R., E.C. Milbrandt, B. Brown, K.W. Krauss, A.S. Rovai, J.W. Beever \& L.L. Flynn (2016). Stress in mangrove forests: early detection and pre-emptive rehabilitation are essential for future successful worldwide mangrove forest management. Marine Pollution Bulletin 109(2): 764-771.

Magurran, A.E. (2004). Ecological diversity and its measurement. Blackwell Science Ltd. USA.

Mahmud, I., M.K. Islam, S. Saha, A.K. Barman, M.M. Rahman, M. Anisuzzman, T. Rahman, A. Al-Nahain, R. Jahan \& M. Rahmatullah (2014). Pharmacological and Ethnomedicinal Overview of Heritiera fomes: Future Prospects. International Scholarly Research Notices 1-12. http://doi.org/10.1155/2014/938543

Mitra, A., K. Banerjee \& D.P. Bhattacharyya (2004). The Other Face of Mangroves. Department of Environment, Govt. of West Bengal, India.

Mohanta, M.R., B.K. Pradhan \& S.C. Sahu (2020). Assessment of species diversity and physicochemical characteristics of mangrove vegetation in Odisha, India, pp. 135-151. In: Patra, J.K., R.S. Mishra \& H. Thatoi (eds). Biotechnological Utilization of Mangrove Resources. Chapter 6. Academic Press, Elsevier, 490pp.

Pascal, J.P. (1988). Wet Evergreen Forests of the Western Ghats of India: Ecology, Structure, Floristic Composition and Succession. Institut Francais de Pondichery, India.

Patwardhan, A., M. Pimputkar, P. Agarwal, N. Barve, R. Gunaga, A. Mirgal, C. Salunkhe \& R. Vasudeva (2016). Distribution and population status of threatened medicinal tree Saraca asoca (Roxb.) De Wilde from Sahyadri-Konkan corridor. Current Science 111(9): 1500-1506.

Polidoro, B.A., K.E. Carpenter, L. Collins, N.C. Duke, A.M. Ellison, J.C. Ellison, E.J. Farnsworth, E.S. Fernando, K Kathiresan, N.E. Koedam, S.R. Livingstone, T. Miyagi, G.E. Moore, V.N. Nam, J.E. Ong, J.H. Primavera, S.G. Salmo III, J.C. Sanciangco, S. Sukardjo, Y Wang \& J.W.H. Yong (2010). The loss of species: mangrove extinction risk and geographic areas of global concern. PLOS ONE 5(4): e10095. https://doi.org/10.1371/journal.pone.0010095

Ravishankar, T., M. Navamuniyammal, L. Gnanappazham, S.S. Nayak, G.C. Mahapatra \& V. Selvam (2004). Atlas of mangrove wetland of India (part-3, Orissa). MS Swaminathan Research Foundation, India. Romanach, S., D. Deangelis, R.B. Sulaiman \& L. Zhai (2018). Conservation and restoration of mangroves: Global status, perspectives, and Prognosis. Ocean and Coastal Management 154: 72-82.

Shengyan, Y., Z. Juncheng \& M.V. Subrahmanyam (2019). Sea surface temperature cooling induced by Tropical cyclone Hudhud over Bay of Bengal. Indian Journal of Geo Marine Sciences 48(1): 9-17.

Stanley, O.D. \& R.R. Lewis III (2009). Strategies for mangrove rehabilitation in an eroded coastline of Selangor, peninsular Malaysia. Journal of Coastal Development 12(3): 144-156.

Tadwalkar, M., A. Joglekar, M. Mhaskar, R. Kanade, B. Chavan, A. Watve, K.N. Ganeshaiah \& A. Patwardan (2012). Dispersal modes of woody species from the northern Western Ghats, India. Tropical Ecology 53(1): 53-67.

Upadhyay, V.P. \& P.K. Mishra (2014). An ecological analysis of mangroves ecosystem of Odisha on the eastern coast of India. Proceedings of the National Academy of Sciences 80(3): 647-661.

Valiela, I., J.L. Bowen \& J.K. York (2001). Mangrove forests: one of the world's threatened major tropical environments. BioScience 51(10): $807-815$

Xin, P., L. Li \& D.A. Barry (2013). Tidal influence on soil conditions in an intertidal creek-marsh system. Water Resource Research 49: 137-150. 
Dr. Albert G. Orr, Griffith University, Nathan, Australia

Dr. Sameer Padhye, Katholieke Universiteit Leuven, Belgium

Dr. Nancy van der Poorten, Toronto, Canada

Dr. Kareen Schnabel, NIWA, Wellington, New Zealand

Dr. R.M. Sharma, (Retd.) Scientist, Zoological Survey of India, Pune, India

Dr. Manju Siliwal, WILD, Coimbatore, Tamil Nadu, India

Dr. G.P. Sinha, Botanical Survey of India, Allahabad, India

Dr. K.A. Subramanian, Zoological Survey of India, New Alipore, Kolkata, India

Dr. P.M. Sureshan, Zoological Survey of India, Kozhikode, Kerala, India

Dr. R. Varatharajan, Manipur University, Imphal, Manipur, India

Dr. Eduard Vives, Museu de Ciències Naturals de Barcelona, Terrassa, Spain

Dr. James Young, Hong Kong Lepidopterists' Society, Hong Kong

Dr. R. Sundararaj, Institute of Wood Science \& Technology, Bengaluru, India

Dr. M. Nithyanandan, Environmental Department, La Ala Al Kuwait Real Estate. Co. K.S.C., Kuwait

Dr. Himender Bharti, Punjabi University, Punjab, India

Mr. Purnendu Roy, London, UK

Dr. Saito Motoki, The Butterfly Society of Japan, Tokyo, Japan

Dr. Sanjay Sondhi, TITLI TRUST, Kalpavriksh, Dehradun, India

Dr. Nguyen Thi Phuong Lien, Vietnam Academy of Science and Technology, Hanoi, Vietnam

Dr. Nitin Kulkarni, Tropical Research Institute, Jabalpur, India

Dr. Robin Wen Jiang Ngiam, National Parks Board, Singapore

Dr. Lional Monod, Natural History Museum of Geneva, Genève, Switzerland.

Dr. Asheesh Shivam, Nehru Gram Bharti University, Allahabad, India

Dr. Rosana Moreira da Rocha, Universidade Federal do Paraná, Curitiba, Brasil

Dr. Kurt R. Arnold, North Dakota State University, Saxony, Germany

Dr. James M. Carpenter, American Museum of Natural History, New York, USA

Dr. David M. Claborn, Missouri State University, Springfield, USA

Dr. Kareen Schnabel, Marine Biologist, Wellington, New Zealand

Dr. Amazonas Chagas Júnior, Universidade Federal de Mato Grosso, Cuiabá, Brasil

Mr. Monsoon Jyoti Gogoi, Assam University, Silchar, Assam, India

Dr. Heo Chong Chin, Universiti Teknologi MARA (UiTM), Selangor, Malaysia

Dr. R.J. Shiel, University of Adelaide, SA 5005, Australia

Dr. Siddharth Kulkarni, The George Washington University, Washington, USA

Dr. Priyadarsanan Dharma Rajan, ATREE, Bengaluru, India

Dr. Phil Alderslade, CSIRO Marine And Atmospheric Research, Hobart, Australia

Dr. John E.N. Veron, Coral Reef Research, Townsville, Australia

Dr. Daniel Whitmore, State Museum of Natural History Stuttgart, Rosenstein, Germany.

Dr. Yu-Feng Hsu, National Taiwan Normal University, Taipei City, Taiwan

Dr. Keith V. Wolfe, Antioch, California, USA

Dr. Siddharth Kulkarni, The Hormiga Lab, The George Washington University, Washington,

D.C., USA

Dr. Tomas Ditrich, Faculty of Education, University of South Bohemia in Ceske

Budejovice, Czech Republic

Dr. Mihaly Foldvari, Natural History Museum, University of Oslo, Norway

Dr. V.P. Uniyal, Wildlife Institute of India, Dehradun, Uttarakhand 248001, India

Dr. John T.D. Caleb, Zoological Survey of India, Kolkata, West Bengal, India

Dr. Priyadarsanan Dharma Rajan, Ashoka Trust for Research in Ecology and the Environment (ATREE), Royal Enclave, Bangalore, Karnataka, India

\section{Fishes}

Dr. Neelesh Dahanukar, IISER, Pune, Maharashtra, India

Dr. Topiltzin Contreras MacBeath, Universidad Autónoma del estado de Morelos, México

Dr. Heok Hee Ng, National University of Singapore, Science Drive, Singapore

Dr. Rajeev Raghavan, St. Albert's College, Kochi, Kerala, India

Dr. Robert D. Sluka, Chiltern Gateway Project, A Rocha UK, Southall, Middlesex, UK

Dr. E. Vivekanandan, Central Marine Fisheries Research Institute, Chennai, India

Dr. Davor Zanella, University of Zagreb, Zagreb, Croatia

Dr. A. Biju Kumar, University of Kerala, Thiruvananthapuram, Kerala, India

Dr. Akhilesh K.V., ICAR-Central Marine Fisheries Research Institute, Mumbai Research

Centre, Mumbai, Maharashtra, India

Dr. J.A. Johnson, Wildlife Institute of India, Dehradun, Uttarakhand, India

\section{Amphibians}

Dr. Sushil K. Dutta, Indian Institute of Science, Bengaluru, Karnataka, India

Dr. Annemarie Ohler, Muséum national d'Histoire naturelle, Paris, France

\section{Reptiles}

Dr. Gernot Vogel, Heidelberg, Germany

Dr. Raju Vyas, Vadodara, Gujarat, India

Dr. Pritpal S. Soorae, Environment Agency, Abu Dubai, UAE.

Prof. Dr. Wayne J. Fuller, Near East University, Mersin, Turkey

Prof. Chandrashekher U. Rivonker, Goa University, Taleigao Plateau, Goa. India

Dr. S.R. Ganesh, Chennai Snake Park, Chennai, Tamil Nadu, India

Dr. Himansu Sekhar Das, Terrestrial \& Marine Biodiversity, Abu Dhabi, UAE
Birds

Dr. Hem Sagar Baral, Charles Sturt University, NSW Australia

Dr. Chris Bowden, Royal Society for the Protection of Birds, Sandy, UK

Dr. Priya Davidar, Pondicherry University, Kalapet, Puducherry, India

Dr. J.W. Duckworth, IUCN SSC, Bath, UK

Dr. Rajah Jayapal, SACON, Coimbatore, Tamil Nadu, India

Dr. Rajiv S. Kalsi, M.L.N. College, Yamuna Nagar, Haryana, India

Dr. V. Santharam, Rishi Valley Education Centre, Chittoor Dt., Andhra Pradesh, India

Dr. S. Balachandran, Bombay Natural History Society, Mumbai, India

Mr. J. Praveen, Bengaluru, India

Dr. C. Srinivasulu, Osmania University, Hyderabad, India

Dr. K.S. Gopi Sundar, International Crane Foundation, Baraboo, USA

Dr. Gombobaatar Sundev, Professor of Ornithology, Ulaanbaatar, Mongolia

Prof. Reuven Yosef, International Birding \& Research Centre, Eilat, Israel

Dr. Taej Mundkur, Wetlands International, Wageningen, The Netherlands

Dr. Carol Inskipp, Bishop Auckland Co., Durham, UK

Dr. Tim Inskipp, Bishop Auckland Co, Durham, UK

Dr. V. Gokula, National College, Tiruchirappalli, Tamil Nadu, India

Dr. Arkady Lelej, Russian Academy of Sciences, Vladivostok, Russia

Dr. Simon Dowell, Science Director, Chester Zoo, UK

Dr. Mário Gabriel Santiago dos Santos, Universidade de Trás-os-Montes e Alto Douro,

Quinta de Prados, Vila Real, Portugal

Dr. Grant Connette, Smithsonian Institution, Royal, VA, USA

Dr. M. Zafar-ul Islam, Prince Saud Al Faisal Wildlife Research Center, Taif, Saudi Arabia

Mammals

Dr. Giovanni Amori, CNR - Institute of Ecosystem Studies, Rome, Italy

Dr. Anwaruddin Chowdhury, Guwahati, India

Dr. David Mallon, Zoological Society of London, UK

Dr. Shomita Mukherjee, SACON, Coimbatore, Tamil Nadu, India

Dr. Angie Appel, Wild Cat Network, Germany

Dr. P.O. Nameer, Kerala Agricultural University, Thrissur, Kerala, India

Dr. Ian Redmond, UNEP Convention on Migratory Species, Lansdown, UK

Dr. Heidi S. Riddle, Riddle's Elephant and Wildlife Sanctuary, Arkansas, USA

Dr. Karin Schwartz, George Mason University, Fairfax, Virginia.

Dr. Lala A.K. Singh, Bhubaneswar, Orissa, India

Dr. Mewa Singh, Mysore University, Mysore, India

Dr. Paul Racey, University of Exeter, Devon, UK

Dr. Honnavalli N. Kumara, SACON, Anaikatty P.O., Coimbatore, Tamil Nadu, India

Dr. Nishith Dharaiya, HNG University, Patan, Gujarat, India

Dr. Spartaco Gippoliti, Socio Onorario Società Italiana per la Storia della Fauna "Giuseppe

Altobello", Rome, Italy

Dr. Justus Joshua, Green Future Foundation, Tiruchirapalli, Tamil Nadu, India

Dr. H. Raghuram, The American College, Madurai, Tamil Nadu, India

Dr. Paul Bates, Harison Institute, Kent, UK

Dr. Jim Sanderson, Small Wild Cat Conservation Foundation, Hartford, USA

Dr. Dan Challender, University of Kent, Canterbury, UK

Dr. David Mallon, Manchester Metropolitan University, Derbyshire, UK

Dr. Brian L. Cypher, California State University-Stanislaus, Bakersfield, CA

Dr. S.S. Talmale, Zoological Survey of India, Pune, Maharashtra, India

Prof. Karan Bahadur Shah, Budhanilakantha Municipality, Kathmandu, Nepal

Dr. Susan Cheyne, Borneo Nature Foundation International, Palangkaraja, Indonesia

Dr. Hemanta Kafley, Wildlife Sciences, Tarleton State University, Texas, USA

\section{Other Disciplines}

Dr. Aniruddha Belsare, Columbia MO 65203, USA (Veterinary)

Dr. Mandar S. Paingankar, University of Pune, Pune, Maharashtra, India (Molecular)

Dr. Jack Tordoff, Critical Ecosystem Partnership Fund, Arlington, USA (Communities)

Dr. Ulrike Streicher, University of Oregon, Eugene, USA (Veterinary)

Dr. Hari Balasubramanian, EcoAdvisors, Nova Scotia, Canada (Communities)

Dr. Rayanna Hellem Santos Bezerra, Universidade Federal de Sergipe, São Cristóvão, Brazil

Dr. Jamie R. Wood, Landcare Research, Canterbury, New Zealand

Dr. Wendy Collinson-Jonker, Endangered Wildlife Trust, Gauteng, South Africa

Dr. Rajeshkumar G. Jani, Anand Agricultural University, Anand, Gujarat, India

Dr. O.N. Tiwari, Senior Scientist, ICAR-Indian Agricultural Research Institute (IARI), New

Delhi, India

Dr. L.D. Singla, Guru Angad Dev Veterinary and Animal Sciences University, Ludhiana, India

Dr. Rupika S. Rajakaruna, University of Peradeniya, Peradeniya, Sri Lanka

Dr. Bahar Baviskar, Wild-CER, Nagpur, Maharashtra 440013, India

Reviewers 2018-2020

Due to pausity of space, the list of reviewers for 2018-2020 is available online.
The opinions expressed by the authors do not reflect the views of the Journal of Threatened Taxa, Wildlife Information Liaison Development Society, Zoo Outreach Organization, or any of the partners. The journal, the publisher, the host, and the partners are not responsible for the accuracy of the political boundaries shown in the maps by the authors.

\footnotetext{
Print copies of the Journal are available at cost. Write to:

The Managing Editor, JoTT,

c/o Wildlife Information Liaison Development Society,

No. 12, Thiruvannamalai Nagar, Saravanampatti - Kalapatti Road,

Saravanampatti, Coimbatore, Tamil Nadu 641035, India

ravi@threatenedtaxa.org
} 


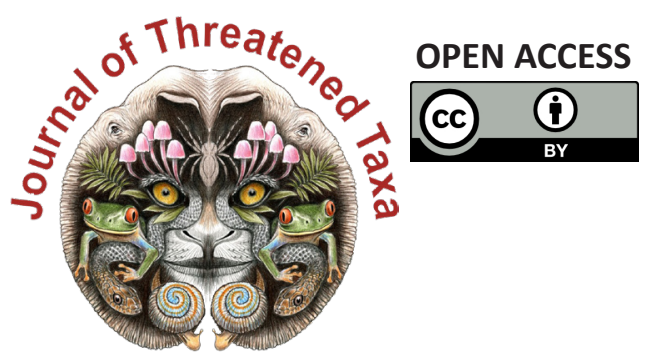

www.threatenedtaxa.org

The Journal of Threatened Taxa (JoTT) is dedicated to building evidence for conservation globally by publishing peer-reviewed articles online every month at a reasonably rapid rate at www.threatenedtaxa.org. All articles published in JoTT are registered under Creative Commons Attribution 4.0 International License unless otherwise mentioned. JoTT allows allows unrestricted use, reproduction, and distribution of articles in any medium by providing adequate credit to the author(s) and the source of publication.

\section{ISSN $0974-7907$ (Online) | ISSN $0974-7893$ (Print)}

\section{October 2021 | Vol. 13 | No. 12 | Pages: 19675-19886 \\ Date of Publication: 26 October 2021 (Online \& Print) DOI: 10.11609/jott.2021.13.12.19675-19886}

Articles

Roosting habits and habitats of the Indian Flying Fox Pteropus medius Temminck, 1825 in the northern districts of Tamil Nadu, India

- M. Pandian \& S. Suresh, Pp. 19675-19688

Diversity and distribution of avifauna at Warathenna-Hakkinda Environmental Protection Area in Kandy, Sri Lanka

- Dinelka Thilakarathne, Tithira Lakkana, Gayan Hirimuthugoda, Chaminda Wijesundara \& Shalika Kumburegama, Pp. 19689-19701

Grass species composition in tropical forest of southern India

- M. Ashokkumar, S. Swaminathan \& R. Nagarajan, Pp. 19702-19713

\section{Communications}

Habitat use and conservation threats to Wild Water Buffalo Bubalus arnee (Mammalia: Artiodactyla: Bovidae) in Koshi Tappu Wildlife Reserve, Nepal

- Reeta Khulal, Bijaya Neupane, Bijaya Dhami, Siddhartha Regmi, Ganesh Prasad Tiwari \& Manita Parajuli, Pp. 19714-19724

Get my head around owls: people perception and knowledge about owls of Andaman Islands

- Shanmugavel Sureshmarimuthu, Santhanakrishnan Babu, Nagaraj Rajeshkumar \& Honnavalli Nagaraj Kumara, Pp. 19725-19732

Abundance and diversity of threatened birds in Nangal Wetland, Punjab, India - Rajwinder Kaur \& Onkar Singh Brraich, Pp. 19733-19742

Evaluation of fish diversity and abundance in the Kabul River with comparisons between reaches above and below Kabul City, Afghanistan

- Ugyen Kelzang, Ahmad Farid Habibi \& Ryan J. Thoni, Pp. 19743-19752

New record of Myrmarachne melanocephala MacLeay, 1839 (Araneae: Salticidae) from Jharkhand, India and biogeographical implications of the co-occurrence of its ant model Tetraponera rufonigra Jerdon, 1851

- Rahul Kumar, Mirtunjay Sharma \& Ajay Kumar Sharma, Pp. 19753-19761

Diversity of spiders (Arachnida: Araneae) and the impact of pruning in Indian sandalwood plantations from Karnataka, India

-S. Padma 1 \& R. Sundararaj, Pp. 19762-19772

New records of cheilostome Bryozoa from the eastern coast of India encrusting on the exoskeleton of live horseshoe crabs of Indian Sundarbans

- Swati Das, Maria Susan Sanjay, Basudev Tripathy, C. Venkatraman \& K.A. Subramanian, Pp. 19773-19780

On the pteridophytes of Bherjan-Borajan-Padumoni Wildlife Sanctuary, Assam, India - Pranjal Borah \& Jayanta Barukial, Pp. 19781-19790

Population status of Heritiera fomes Buch.-Ham., a threatened species from Mahanadi Mangrove Wetland, India

- Sudam Charan Sahu, Manas Ranjan Mohanta \& N.H. Ravindranath, Pp. 19791-19798

Additions to the lichenized and lichenicolous fungi of Jammu \& Kashmir from Kishtwar High Altitude National Park

- Vishal Kumar, Yash Pal Sharma, Siljo Joseph, Roshinikumar Ngangom \& Sanjeeva Nayaka, Pp. 19799-19807

\section{Short Communications}

Is release of rehabilitated wildlife with embedded lead ammunition advisable? Plumbism in a Jaguar Panthera Onca (Mammalia: Carnivora: Felidae), survivor of gunshot wounds - Eduardo A. Díaz, Carolina Sáenz, E. Santiago Jiménez, David A. Egas \& Kelly Swing, Pp. 19808-19812

New record of the Sewing Needle Zipper Loach Paracanthocobitis linypha Singer \& Page, 2015 (Teleostei: Cypriniformes: Nemacheilidae) from the Chindwin drainage of Manipur, India

- Yumnam Rameshori, Yengkhom Chinglemba \& Waikhom Vishwanath, Pp. 19813-19817

Field identification characters to diagnose Microhyla mukhlesuri from closely related M. mymensinghensis (Amphibia: Microhylidae) and range extension of $M$. mukhlesuri up to West Bengal State, India

- Suman Pratihar \& Kaushik Deuti, Pp. 19818-19823
First report of Scipinia horrida (Stål) (Heteroptera: Reduviidae) from Assam, with comments on related genus Irantha Stål

- Anjana Singha Naorem, Santana Saikia, Anandita Buragohain, Rubina Azmeera Begum, Swapnil S. Boyane \& Hemant V. Ghate, Pp. 19824-19830

Flesh fly (Diptera: Sarcophagidae): male terminalia, diversity and expanded geographical distribution from India

- Kanholi Sreejith, Shuvra Kanti Sinha, Santanu Mahato \& Edamana Pushpalatha, Pp. 1983119836

Checklist of moths (Heterocera) of Tadong, Sikkim, India

- Prayash Chettri, Yuki Matsui, Hideshi Naka \& Archana Tiwari, Pp. 19837-19848

New distribution records of Begonia L., B. murina Craib and B. poilanei Kiew (Begoniaceae: Cucurbitales) for Laos

- Phongphayboun Phonepaseuth, Phetlasy Souladeth, Soulivanh Lanorsavanh, Shuichiro Tagane, Thyraphon Vongthavone \& Keooudone Souvannakhoummane Pp. 19849-19854

Notes

A recent sighting of the Stripe-backed Weasel Mustela strigidorsa (Mammalia: Carnivora: Mustelidae) in Hkakabo Razi Landscape, Myanmar

- Sai Sein Lin Oo, Tun Tun, Kyaw Myo Naing \& Paul Jeremy James Bates, Pp. 19855-19859

Are the uplifted reef beds in North Andaman letting nesting Olive Ridley Sea Turtle Lepidochelys olivacea stranded?

- Nehru Prabakaran, Anoop Raj Singh \& Vedagiri Thirumurugan, Pp. 19860-19863

First record of the orb-weaving spider Araneus tubabdominus Zhu \& Zhang, 1993 (Araneae: Araneidae) from India

- Souvik Sen, John T.D. Caleb \& Shelley Acharya, Pp. 19864-19866

The genus Catapiestus Perty, 1831 (Coleoptera: Tenebrionidae: Cnodalonini) from Arunachal Pradesh with one new record to India

- V.D. Hegde \& Sarita Yadav, Pp. 19867-19869

Rediscovery and extended distribution of Indigofera santapaui Sanjappa (Leguminosae: Papilionoideae) from the states of Maharashtra and Gujarat, India

- Kumar Vinod Chhotupuri Gosavi, Sanjay Gajanan Auti, Sharad Suresh Kambale \& Munivenkatappa Sanjappa, Pp. 19870-19873

Additional distribution records of Ceropegia anjanerica, an endemic and 'Endangered' lantern flower of the northern Western Ghats, India

- Samir Shrikant Maity, Ajay Natha Gangurde, Sharad Suresh Kambale, Avinash Ramchandra Gholave, Avinash Asraji Adsul, Ganesh Babaso Pawar \& Kumar Vinod Chhotupuri Gosavi, Pp. 19874-19877

Notes on the extended distribution of Impatiens megamalayana, a recently described balsam in Western Ghats, India

- Anoop P. Balan \& A.J. Robi, Pp. 19878-19883

Book Review

A look over on the scented tree of India (Santalum album - S. Suresh Ramanan \& A. Arunachalam, Pp. 19884-19886
Publisher \& Host
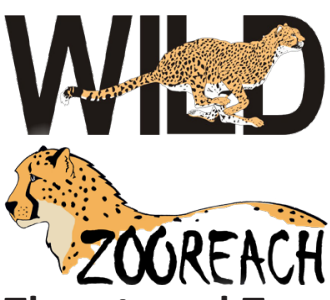

Threatened Taxa 